Fascist Modernities 
STUDIES ON THE HISTORY OF SOCIETY AND CULTURE

Victoria E. Bonnell and Lynn Hunt, Editors 


\section{Fascist Modernities}

Italy, 1922-1945

RUTH BEN-GHIAT

University of California Press

BERKELEY LOS ANGELES LONDON 
Portions of this book are adapted from the following: Ruth Ben-Ghiat, "Fascism, Writing, and Memory: The Realist Aesthetic in Italy, 19301950," Journal of Modern History. Copyright 1995 by The University of Chicago Press. All rights reserved. Ruth Ben-Ghiat, "Envisioning Modernity: Desire and Discipline in the Italian Fascist Film," Critical Inquiry. Copyright 1996 by The University of Chicago Press. All rights reserved.

University of California Press

Berkeley and Los Angeles, California

University of California Press, Ltd.

London, England

(C) 2001 by the Regents of the University of California

Library of Congress Cataloging-in-Publication Data

Ben-Ghiat, Ruth.

Fascist modernities : Italy, 1922-1945 / Ruth Ben-Ghiat.

p. $\quad \mathrm{cm}$.

Includes bibliographical references and index.

ISBN 0-520-22363-2 (cloth : alk. paper).

1. Fascism and culture-Italy-History. 2. Fascism-Italy-

History. 3. Italy-Politics and government-1922-1945.

4. Italy-Intellectual life-2oth century. I. Title. DG571.B 43762001

$945.091-\mathrm{dc} 21$

99-087279

CIP

Manufactured in the United States of America
$\begin{array}{llllllllll}09 & 08 & 07 & 06 & 05 & 04 & 03 & 02 & \text { O1 } & \text { 00 }\end{array}$
$\begin{array}{llllllllll}10 & 9 & 8 & 7 & 6 & 5 & 4 & 3 & 2 & 1\end{array}$

The paper used in this publication meets the minimum requirements of ANSI/NISO Z39.48-1992 (R 1997) (Permanence of Paper). (-) 